\title{
The effect of feeding dairy heifers diets with and without supplemental phosphorus on growth, reproductive efficiency, health, and lactation performance ${ }^{1}$
}

\author{
D. W. Bjelland, ${ }^{2}$ K. A. Weigel, ${ }^{\star}$ P. C. Hoffman, ${ }^{*}$ N. M. Esser, ${ }^{*}$ and W. K. Coblentz† \\ *Department of Dairy Science, University of Wisconsin, Madison 53706 \\ †US Dairy Forage Research Center, Marshfield, WI 54449
}

\section{ABSTRACT}

The phosphorus requirements for dairy heifers $(0.20$ $0.35 \%)$ and endogenous concentrations $(0.20-35 \%)$ of $\mathrm{P}$ in feeds fed to dairy heifers are similar, suggesting that the need for supplemental $\mathrm{P}$ in dairy heifer diets may be minimal. Because long-term $\mathrm{P}$ feeding studies on dairy heifers are unavailable, 183 Holstein heifers and 182 backcross Holstein $\times$ Jersey heifers were offered diets with ( $\mathrm{SP}=0.40 \%$ of dry matter) and without (NP $=0.30 \%$ of dry matter) supplemental $\mathrm{P}$ from 4 to 22 mo of age in a replicated pen design. Forty-eight pens of 8 heifers each were split evenly by breed and treatment group. Heifers were evaluated for body weight (BW), external bone/frame growth, dystocia, calf BW, reproductive efficiency, and first-lactation performance. Growth phase data were analyzed using pen-based statistical models, and lactation data were analyzed using mixed linear models with effects of season of birth, age of dam, heifer pen, sire, sire birth year, and days in milk. Heifers fed NP had similar average daily gain from 170 to 410 and from 410 to $650 \mathrm{~d}$ of age compared with heifers fed SP. At 22 mo of age, heifers fed NP did not differ in BW, hip height, hip width, body length, heart girth, cannon bone circumference, or pelvic area compared with heifers fed SP. Blood P concentrations between heifers fed SP or NP did not differ at 8 or 18 mo of age, and heifers fed SP excreted more P (29.2 vs. $24.2 \mathrm{~g} / \mathrm{d}$ ) than heifers fed NP. As heifers, services per conception and age at pregnancy were not different between heifers fed NP or SP. At parturition, heifers fed NP or SP had similar dystocia scores and calves were similar in BW. Complete first-lactation data (305 d) were available for 333 primiparous cows, and cows fed $\mathrm{NP}$ as heifers produced similar milk, fat, and protein

Received June 1, 2011.

Accepted August 19, 2011.

${ }^{1}$ Mention of trade names or commercial products in this article is solely for the purpose of providing specific information and does not imply either recommendation or endorsement by the US Department of Agriculture.

${ }^{2}$ Corresponding author: dbjelland@wisc.edu compared with cows fed SP as heifers. Days open, days in milk at first breeding, and services per conception also were similar for primiparous cows fed NP or SP as heifers. No growth, reproductive, or lactation benefit was found by feeding dairy heifers diets containing $0.40 \% \mathrm{P}$ compared with $0.30 \% \mathrm{P}$. Furthermore, $\mathrm{P}$ supplemented to SP heifers was simply excreted in the feces and not retained.

Key words: phosphorus, heifer, excretion

\section{INTRODUCTION}

The goal of a dairy replacement heifer management program is to rear heifers at a low economic and environmental cost without compromising future lactation performance (Esser et al., 2009). Dairy heifers require adequate amounts of dietary $\mathrm{P}$ for proper growth (NRC, 2001), but feeding excessive dietary P can result in increased $\mathrm{P}$ excretion. Feeding ruminants excess amounts of dietary $\mathrm{P}$ has resulted in excessive manure $\mathrm{P}$ concentrations (Morse et al., 1992), and land application of these manures has been linked to environmental pollution of surface waters (Knowlton et al., 2004). The dietary $\mathrm{P}$ requirements for dairy heifers as defined by NRC (2001) are the sum of $\mathrm{P}$ required for maintenance, growth, and pregnancy divided by feed absorption coefficient(s) for dietary P. The similarity of endogenous concentrations of $\mathrm{P}$ found in feed $(0.20$ $0.35 \%$ of $\mathrm{DM})$ and the dietary $\mathrm{P}$ requirement for dairy heifers $(0.20-0.35 \%$ of DM) provided by NRC (2001) suggest that minimal supplementation of $\mathrm{P}$ is needed. In a short-term experiment, Noller et al. (1977) reported no effect on dairy heifer growth or reproductive performance when supplementing $\mathrm{P}$ at 0.10 percentage units above endogenous concentrations $(0.22 \%$ of DM) in feedstuffs. Furthermore, no negative effects on dairy heifer estrous behavior or endocrine function were reported by Hurley et al. (1982) when dairy heifers were offered diets containing $0.19 \% \mathrm{P}$ compared with diets containing 0.36 and $0.64 \%$ P. Erickson et al. (1999, 2002) reported that growth and carcass composition were not altered in growing beef cattle when basal diets 
without supplemental P supplied 0.14 to $0.19 \%$ P, suggesting that supplemental $\mathrm{P}$ was not required.

In field research on commercial dairy farms, Zygarlicke and Hoffman (2002) observed that it was not uncommon for dairy heifers to be offered diets containing $>0.38 \%$ dietary P. Because dietary $\mathrm{P}$ is integral to skeletal growth and a known positive correlation between skeletal size at first calving and first-lactation milk yield (Hoffman and Funk, 1992) exists, supplementation with $\mathrm{P}$ on commercial dairy farms may be an attempt to ensure that skeletal growth is not compromised. In addition, Knowlton et al. (2004) noted that luxury amounts of $\mathrm{P}$ may be offered to dairy heifers by commercial dairy producers as a possible hedge to improve reproductive performance. Even though several studies have evaluated feeding luxury amounts of $\mathrm{P}$ to lactating cows (Wu et al., 2000; Knowlton and Herbein, 2002), to date no long-term studies have accepted or refuted the concept that feeding luxury amounts of $\mathrm{P}$ to dairy heifers increases frame size at first calving, future lactation performance, health, or fertility.

Due to a void of long-term studies, a long-term experiment was implemented at the Integrated Dairy Research Facility (Marshfield, WI) at the University of Wisconsin to explore the effects of feeding excess $\mathrm{P}$ to growing heifers. Characteristics of bone development in dairy heifers from this experiment have been reported previously (Esser et al., 2009). In that report, the effects of dietary $\mathrm{P}$ on bone development (specifically bone density, composition, growth, and metabolism) were defined. The report concluded that additional supplementation with $\mathrm{P}$ does not affect bone growth, density, or metabolism if endogenous feedstuffs provide adequate P. Esser et al. (2009) did observe that higher amounts of $\mathrm{P}$ in the diet resulted in greater retention of $\mathrm{P}$ in the bone. The present study is a continuance of the work of Esser et al. (2009) with 2 primary objectives. The first objective of this study was to determine if supplementing $\mathrm{P}$ above endogenous concentrations of $\mathrm{P}$ in feedstuffs alters growth, fertility, or nutrient excretion in dairy heifers. The second objective was to determine if supplementing $\mathrm{P}$ to dairy heifers has any carry-over effect on milk yield, health, or reproductive performance of primiparous cows.

\section{MATERIALS AND METHODS}

All animal handling and experimental procedures were approved by the Research Animal Resource Committee at the University of Wisconsin-Madison.

\section{Background}

A 2-part, long-term trial was initiated at the Integrated Dairy Research Facility at the University of
Wisconsin to investigate the effects of $\mathrm{P}$ feeding strategies on the bone development, nutrient utilization, growth, reproductive efficiency, health, and future milk yield of dairy heifers. Because this is a companion study examining heifer growth, nutrient excretion, reproductive performance, and carry-over lactation effects associated with supplementing dairy heifers dietary P, the materials and methods were not appreciably different from those previously reported by Esser et al. (2009). For ease of readership, only a general overview of these methods is offered here. Holstein $(\mathrm{n}=183)$ and Holstein $\times$ Jersey crossbred heifers $(\mathrm{n}=182)$ were assigned to 1 of 2 dietary $\mathrm{P}$ treatments arranged as a $2 \times 2$ factorial design with breed and dietary $\mathrm{P}$ as main effects. The 2 dietary treatments differed in that one was supplemented with monosodium phosphate to increase the dietary $\mathrm{P}$ by $0.10 \%$ of $\mathrm{DM}$, whereas the other treatment contained no supplemental P. The methods of the present study outlined by Esser et al. (2009) were similar to those reported by Noller et al. (1977), but differed in 3 specific ways. First, the dietary treatments were initiated at 4 mo of age and continued for the entire growth period $(\sim 600 \mathrm{~d})$ compared with the 238- and 364-d feeding intervals implemented by Noller et al. (1977). The second difference was that a larger number of animals $(\mathrm{n}=365)$ was included in this study to provide enough power to analyze reproductive performance, health, and carry-over lactation effects. The third difference was that the current project included data involving bone growth, bone composition, and bone metabolism. Bone composition and bone metabolism were previously reported by Esser et al. (2009); therefore, those traits are not included in this report. Data presented in this paper include heifer growth, nutrient excretion, reproductive performance, and carry-over lactation effects associated with dietary $\mathrm{P}$ concentrations in dairy heifer diets.

At approximately 4 mo of age, 8 Holstein or crossbred heifers were assigned to a $4.3-\times 6.5-\mathrm{m}$ pen that was bedded with wood shavings and provided $0.55 \mathrm{~m}$ of bunk space per heifer. Breeds were not commingled and were assigned to separate, breed-specific pens in which they were housed together for the entire treatment period. In total, 48 pens containing 8 heifers per pen were assigned to the long-term pen-replicated trial. Semi-monthly sampling of forages, grains, and protein supplements offered to heifers was performed, and samples were evaluated for DM by drying at $55^{\circ} \mathrm{C}$ for $48 \mathrm{~h}$. Samples were then milled through an Udy mill (Udy Corp., Boulder, CO) fitted with a 1-mm screen and saved for nutrient analysis. Ground samples were dried at $105^{\circ} \mathrm{C}$ for $3 \mathrm{~h}$ to determine residual DM. Nearinfrared reflectance spectroscopy (model 6500, FOSSNIR System, Silver Spring, MD) was performed by the 
University of Wisconsin Soil and Forage Analysis Laboratory (Marshfield, WI) to determine the $\mathrm{CP}$, NDF, NDF-CP, and fat content of forage and grain samples. Samples were ashed at $500^{\circ} \mathrm{C}$ for $2 \mathrm{~h}$ and atomic absorption spectroscopy was used to determine $\mathrm{Ca}, \mathrm{K}$, and $\mathrm{Mg}$ content of all feeds and colorimetric methods (Schulte et al., 1987) were used to determine $\mathrm{P}$ concentrations. Total digestible nutrients, $\mathrm{ME}, \mathrm{NE}_{\mathrm{G}}$, and $\mathrm{NE}_{\mathrm{M}}$ of forages, grains, and protein supplements offered to heifers were estimated using summative equations (NRC, 2001).

After semi-monthly forage and grain analyses were completed, 3 separate rations were formulated for small $(<275 \mathrm{~kg})$, medium (275 to $450 \mathrm{~kg}$ ), and large $(>450 \mathrm{~kg})$ Holstein heifers according to NRC (2001) requirements. Different weight criteria $(<250,250$ to $425,>425 \mathrm{~kg}$ ) were used to account for their difference in physiological maturity and body size (NRC, 2001) but the same diets were fed to crossbred and Holstein heifers. Heifers were fed by pen once daily at $0800 \mathrm{~h}$.

The DM contents of forages were monitored daily, and adjustments were made when forage DM changed by more than 4.0 percentage units. A bunk scoring system was used to monitor daily feed consumption of each pen of heifers to maintain an optimal amount of orts (bunk score of 1). Each day at $0730 \mathrm{~h}$, before feeding, feed bunks were scored by 1 of 2 staff members and classified as 0 (no feed remaining), 1 (few and scattered feed particles remaining), 2 (bottom of feed bunk covered in thin layer of feed), or 3 (large amounts of feed remaining with the bottom of the feed bunk not visible). Orts were not weighed for heifer pens with bunk scores $<2$ because the amount of feed remaining was negligible $(<1.0 \mathrm{~kg})$. Orts from bunk scores of 2 or 3 were weighed and subtracted from the daily feed offering for that pen. The DM content of the orts was not measured, and the DM content of the diet was used as a surrogate.

Heifers were weighed at $60-\mathrm{d}$ intervals, from 4 to 22 mo of age, using a cattle chute (Real Tuff, Clearbrook, MN) fitted with an electronic scale (Tru-Test Inc., Mineral Wells, TX). At this time, measurements of hip height, body length, heart girth, and BCS were also taken (Esser et al., 2009). Average daily gain was calculated for each heifer during 2 intervals, 170 to 410 $\mathrm{d}$ of age and 410 to $650 \mathrm{~d}$ of age, to compare the differences of early and late heifer growth stages. Pelvic height, width, and calculated pelvic area were determined using a calibrated pelvic forceps (HCR, Wright City, MO).

At 2 intermediary periods of growth, 8 and 18 mo of age, blood samples were collected from 122 heifers, balanced by breed and experimental diets, and evalu- ated for blood $\mathrm{P}$ concentrations. Samples were taken $3 \mathrm{~h}$ postfeeding via the jugular vein into blood serum separator tubes (BD Vacutainer, Franklin Lakes, NJ). Blood samples were immediately cooled by placing the tubes in ice and transferred to Marshfield Laboratories (Marshfield, WI) for blood P analysis.

A subset of heifer pens $(\mathrm{n}=24)$, balanced by treatment and breed at 2 BW classifications (light $=349.4 \pm$ 55.5 and heavy $=553.1 \pm 31.9 \mathrm{~kg}$ ), was selected for collection of pen nutrient excretion data. Heifers classified as light and heavy were on their respective treatment diets for approximately 240 and 460 d, respectively, before nutrient excretion data were collected. Nutrient excretion data were not collected from 2 pens (1 Holstein pen fed SP and 1 Holstein pen fed NP) originally selected for nutrient excretion measurements because extreme cold temperatures prohibited manure collections. As a result, data from 22 pen nutrient excretions were used in the final analysis. When a preselected pen of heifers reached appropriate BW criteria, the pen of heifers was moved to a clean manure collection pen for $48 \mathrm{~h}$. Pens were bedded with approximately $35 \mathrm{~kg}$ of wood shavings distributed evenly throughout the pen. Prior to heifers moving into the pen, 5 random areas of wood shavings were selected to ascertain DM, N, and $\mathrm{P}$ contents. Wood shaving composites were dried for 24 $\mathrm{h}$ in a $55^{\circ} \mathrm{C}$ forced air oven, ground using a Wiley mill with a 1-mm screen, and saved for nutrient analysis. Boards $(0.05 \times 0.20 \mathrm{~m})$ were used to form a perimeter around the manure collection pen to prevent contamination from neighboring pens. Assigned treatment diets were fed to heifers in the manure collection pens, and after $48 \mathrm{~h}$, heifers were returned to their original pens. All bedding, feces, and urine excreted during the 48-h collection period were transferred with a skid steer or manually shoveled into a $4.4-\mathrm{m}^{3}$ manure spreader (H\&S Manufacturing Company Inc., Marshfield, WI) equipped with electronic load cells and monitor (DigiStar, Fort Atkinson, WI). All contents of the manure spreader were weighed, mixed, and discharged onto a concrete slab, where 6 samples of the mixture were taken for analysis of $\mathrm{N}$ contents according to the AOAC (1990) methods before drying. The $\mathrm{N}$ excretion data can only be interpreted as apparent, because $\mathrm{N}$ volatilization during the pen manure collection period (48 h) could not be accounted for (Varel et al., 1999). The remaining samples were dried at $55^{\circ} \mathrm{C}$ for $48 \mathrm{~h}$, ground through a Wiley mill with a $1-\mathrm{mm}$ screen, and saved for $\mathrm{P}$ analysis. All dietary ingredients offered during nutrient excretion collection were sampled daily beginning 2 $\mathrm{d}$ before excretion collection and continuing throughout the heifers' time in the collection pen. Samples were dried at $55^{\circ} \mathrm{C}$ for $48 \mathrm{~h}$, ground through a Wiley mill 
with a 1-mm screen, composited on a dried ground basis, and saved for subsequent $\mathrm{N}$ and $\mathrm{P}$ analysis.

The $\mathrm{N}$ and $\mathrm{P}$ contents of the pen manure (bedding, urine, and feces), wood shavings, and feedstuffs were determined by macro-Kjeldahl (AOAC, 1990) and colorimetric methods (Schulte et al., 1987), respectively. Pen $\mathrm{N}$ and $\mathrm{P}$ excretions were calculated by subtracting the contribution of $\mathrm{N}$ and $\mathrm{P}$ of the wood shavings from the total of the pen bedding and manure $\mathrm{N}$ and $\mathrm{P}$. Mean pen $\mathrm{N}$ and $\mathrm{P}$ intake from the recorded intervals were used to estimate apparent $\mathrm{N}$ and $\mathrm{P}$ retention.

First-lactation health, reproductive, and production data, as well as reproductive data of nulliparous heifers, were obtained from Dairy Comp 305 files (Valley Ag Software, Tulare, CA). Health traits included the incidence of any hoof disease, injury, or clinical mastitis. For statistical analysis, these health disorders were reported as the percentage of primiparous cows with a given disorder during the first lactation.

Measures of reproductive performance, such as services per conception as a heifer, age at pregnancy, gestation length, DIM at first breeding, first lactation services per conception, days open, and the percentage of animals pregnant by 150 and $250 \mathrm{~d}$ postpartum were recorded. Calving ease and calf BW were also measured. Calving ease was recorded on a 5-point ordinal scale as defined by Cole et al. (2005). All calvings labeled as 1 or 2 were classified as 0 (no assistance) and calvings labeled as 3,4 , or 5 were classified as 1 (assistance required). Dystocia indexes were compressed to indicate the percentage of NP and SP heifers that required calving assistance, without detailed delineation. For statistical analysis of days open, all nonpregnant primiparous cows were required to be at least $250 \mathrm{~d}$ postpartum to be included in the analyses. All primiparous cows $\geq 250 \mathrm{~d}$ open were set to $250 \mathrm{~d}$, regardless of whether or not they were pregnant. Primiparous cows designated as "do not breed" before reaching 250 d postpartum, regardless of reason, were removed from the reproductive analyses. When analyzing the percentage of primiparous cows pregnant at a given DIM, each nonpregnant cow was required to be at least 150 or 250 $\mathrm{d}$ postpartum to be included in each analysis to afford an opportunity for the cow to become pregnant.

Production traits included 305-d milk yield, 305-d mature-equivalent milk yield, peak milk yield, total milk yield, total fat yield, total protein yield, 3.5\% FCM yield, $\log$ SCC, MUN, and milking speed. Primiparous cows were required to be at least $100 \mathrm{~d}$ postpartum to be included in the analyses for production criteria, with over $90 \%$ of the cows having at least $300 \mathrm{~d}$ postpartum. The 3.5\% FCM, log SCC, MUN, and milking speed of primiparous cows were defined as the mean of all measurements for the entire lactation.

\section{Statistical Analysis}

All statistical analyses were performed using version 2.72 of $\mathrm{R}$ (R Foundation for Statistical Computing, 2008). Two separate statistical approaches were used in this study. Growth phase BW, BCS, frame size, ADG, blood $\mathrm{P}$ concentration, $\mathrm{P}$ intake, $\mathrm{P}$ excretion, and apparent $\mathrm{P}$ retention, as well as heifer reproductive criteria of services per conception, age at pregnancy, and gestation length used heifer pen as the experimental unit. Growth phase data were analyzed using penbased statistical models similar to those described by St-Pierre (2007) with the fixed effects of dietary treatment and breed and the random effect of pen nested within dietary treatment and breed.

A second statistical method was used on the lactation phase data, which included dystocia index; calf BW; DIM at first breeding; services per conception; days open; percentage of cows pregnant by 150 and 250 d postpartum; incidence of mastitis, hoof disease, and injury; and all lactation yield traits. Because primiparous cows during the lactation phase were separated and no longer penned together, the experimental unit for lactation phase data was the individual cow rather than pen, although pen as a heifer was included as a random variable in each evaluation. The statistical analyses of most lactation phase data were conducted using linear mixed models, with the exception of services per conception, which was analyzed using Poisson regression, and dystocia index, percentage pregnant by 150 or $250 \mathrm{~d}$ postpartum, and the incidences of mastitis, hoof disease, and injury, which were analyzed using logistic regression. Fixed explanatory variables of breed, season-year of birth, age of dam, sire birth year, and DIM at time of collection (for lactation yield data) were considered for each model, as well as a random heifer pen effect and a random paternal genetic effect. Backward deletion Akaike's information criterion was performed, starting with the full models, to find a suitable model for each trait to calculate least squares means and significance tests. Because no breed $\times$ dietary treatment interactions were found, only the main effects of the dietary treatment are presented.

\section{RESULTS AND DISCUSSION}

Mean ingredient and nutrient composition of experimental diets containing 0.30 or $0.40 \% \mathrm{P}$ offered to Holstein and crossbred heifers from 4 to 22 mo of age are presented in Table 1 . The mean ingredient nutrient compositions of NP and SP diets offered to heifers are similar to those reported by Esser et al. (2009). Although taken from the same study, minor differences between the ingredient and nutrient composition data 
exist for the growth phase of the study, because Esser et al. (2009) evaluated only a portion of the total heifers assigned to the study for bone metabolism. Heifers fed NP and SP were provided diets with similar ingredients and nutrient compositions, with the exception that the SP experimental diet contained supplemental $\mathrm{P}$ in the form of monosodium phosphate from 4 to 22 mo of age, and the NP experimental diet contained a similar mineral-vitamin premix, with bentonite replacing monosodium phosphate at an equivalent amount of DM.

\section{Heifer Body Measurements}

Least squares means for 22-mo skeletal measurements and ADG measurements for heifers fed SP and NP from 4 to 22 mo of age are presented in Table 2 . At 22 mo of age, BW, BCS, hip height, hip width, body length, heart girth, cannon bone circumference, pelvic height, pelvic width, pelvic area, and pelvic length did not differ $(P \geq 0.10)$ between treatment groups. The consistency in frame size was exhibited throughout the growth phase, as individual statistical analyses of BW, BCS, heart girth, body length, and hip height measured at $170,230,290,350,410,470,530,590$, and 650 $\mathrm{d}$ of age did not differ on the basis of dietary treatment $(P \geq 0.10)$, as shown for BW in Figure 1. The ADG of heifers offered NP and SP diets between 170 and 410 $\mathrm{d}$ of age were 0.85 and $0.83 \mathrm{~kg} / \mathrm{d}$, respectively, and did not differ $(P=0.48)$. The ADG of heifers from $410 \mathrm{~d}$ to $650 \mathrm{~d}$ of age also did not differ $(P=0.40)$ with dietary treatment.

In the companion study, Esser et al. (2009) analyzed the same skeletal measurements as those discussed here on a balanced subset of the heifers and did not observe differences in skeletal growth due to supplemental P. The analysis in the present trial used a much larger population of heifers and confirmed the observation of Esser et al. (2009) that supplementing dairy heifers with $\mathrm{P}$ at $0.40 \%$ of DM compared with $0.30 \%$ of $\mathrm{DM}$ has no effect on BW or skeletal growth. Furthermore, Esser et al. (2009) performed bone density scans on the 13th coccygeal vertebrae using peripheral quantitative computed tomography at the University of Wisconsin School of Veterinary Medicine (Madison, WI). No observed differences in trabecular or cortical bone density of coccygeal vertebrae were found between heifers offered NP and SP diets. In addition, the bone metabolism measured by serum pyridinoline and osteocalcin concentrations, which would indicate bone resorption and formation, respectively, did not differ with diet. Serum pyridinoline concentrations were assessed in duplicate using an ELISA test (Metra Serum Pyd, Quidel Corp., San Diego, CA) by procedures defined by Lang
Table 1. Ingredient and nutrient composition of experimental diets with and without supplemental P offered to Holstein and crossbred heifers from 4 to 22 mo of age

\begin{tabular}{|c|c|c|}
\hline \multirow[b]{2}{*}{ Item } & \multicolumn{2}{|c|}{ Experimental $\operatorname{diet}^{1}$} \\
\hline & $\mathrm{NP}$ & SP \\
\hline \multicolumn{3}{|l|}{ Ingredient } \\
\hline Corn silage & 26.9 & 28.7 \\
\hline Legume silage & 50.2 & 50.1 \\
\hline Small grain silage & 12.0 & 13.5 \\
\hline Grain $\operatorname{mix}^{2}$ & 4.05 & 3.96 \\
\hline Grass hay & 0.13 & 0.15 \\
\hline Sorghum silage & 6.44 & 3.22 \\
\hline Calcium carbonate & 0.03 & 0.03 \\
\hline $\mathrm{P}$ mineral-vitamin premix ${ }^{3}$ & - & 0.31 \\
\hline Mineral-vitamin premix ${ }^{4}$ & 0.31 & - \\
\hline \multicolumn{3}{|l|}{ Nutrient composition } \\
\hline DM, \% & 43.7 & 43.2 \\
\hline $\mathrm{CP}$ & 15.3 & 15.1 \\
\hline $\mathrm{ADF}$ & 30.8 & 31.1 \\
\hline $\mathrm{NDF}$ & 43.3 & 43.0 \\
\hline NFC & 32.0 & 31.4 \\
\hline Fat & 2.41 & 2.38 \\
\hline $\mathrm{Ca}$ & 0.78 & 0.77 \\
\hline $\mathrm{P}$ & 0.30 & 0.40 \\
\hline $\mathrm{Mg}$ & 0.23 & 0.26 \\
\hline $\mathrm{K}$ & 2.08 & 2.04 \\
\hline $\mathrm{S}$ & 0.27 & 0.27 \\
\hline Ash & 7.92 & 7.76 \\
\hline Total digestible nutrients ${ }^{5}$ & 64.8 & 63.5 \\
\hline $\mathrm{NE}_{\mathrm{M}}, \mathrm{Mcal} / \mathrm{kg}$ & 1.51 & 1.50 \\
\hline $\mathrm{NE}_{\mathrm{G}}, \mathrm{Mcal} / \mathrm{kg}$ & 0.92 & 0.92 \\
\hline
\end{tabular}

${ }^{1}$ All values expressed as a percentage of DM unless otherwise indicated. $\mathrm{NP}=$ no supplemental $\mathrm{P}, \mathrm{SP}=$ supplemental $\mathrm{P}$.

${ }^{2}$ Grain mix $=$ combination of oat hulls, shelled corn, and soybean meal (16.1\% CP, $5.0 \% \mathrm{ADF}, 2.8 \%$ fat, $0.5 \% \mathrm{Ca}, 0.2 \% \mathrm{P})$.

${ }^{3} \mathrm{P}$ mineral-vitamin premix $=1.2 \% \mathrm{Ca}, 14.5 \% \mathrm{P}, 0.52 \mathrm{Mg}, 3.4 \% \mathrm{~S}$, $2.1 \% \mathrm{Cl}, 12.0 \% \mathrm{Na}, 88,120 \mathrm{IU} / \mathrm{kg}$ of vitamin $\mathrm{A}, 29,640 \mathrm{IU} / \mathrm{kg}$ of vitamin $\mathrm{D}$, and $798 \mathrm{IU} / \mathrm{kg}$ of vitamin $\mathrm{E}$.

${ }^{4}$ Mineral-vitamin premix $=1.2 \% \mathrm{Ca}, 0.0 \% \mathrm{P}, 0.0 \% \mathrm{Mg}, 3.4 \% \mathrm{~S}, 10.1 \%$ $\mathrm{Cl}, 6.6 \% \mathrm{Na}, 88,120 \mathrm{IU} / \mathrm{kg}$ of vitamin A, 29,640 IU/kg of vitamin D, and $798 \mathrm{IU} / \mathrm{kg}$ of vitamin E.

${ }^{5}$ As calculated by NRC (2001).

et al. (2001), and serum osteocalcin concentrations were determined in duplicate using an ELISA test (Metra Osteocalcin, Quidel Corp.) as described by Peterson et al. (2005). The similarities of BW and frame size for heifers fed SP and NP diets in the (expanded) present study are reasonable, based on the previous lack of response to supplemental $\mathrm{P}$ for bone growth, density, and metabolism.

The effects of supplemental $\mathrm{P}$ on heifer growth in this trial are consistent with those in other studies. Noller et al. (1977) discovered no difference in BW or ADG when comparing dairy heifers offered diets with 0.22 or $0.32 \%$ P. Results from various other livestock species came to similar conclusions. Erickson et al. (1999) fed crossbred beef steers diets containing (\% of DM) 0.14, $0.19,0.24,0.29$, or $0.34 \%$ P from $386 \mathrm{~kg}$ to finishing. No differences were observed for steer growth, feed efficiency, tenderness, or skeletal maturity due to an 
Table 2. Least squares means of BW, BCS, frame size, ADG, and blood $\mathrm{P}$ for heifers 22 mo of age when offered diets with and without supplemental P from 4 to 22 mo of age

\begin{tabular}{lcccc}
\hline & \multicolumn{2}{c}{ Treatment $^{1}$} & & \\
\cline { 2 - 3 } Item & NP & SP & SEM & P-value \\
\hline BW, kg & 604 & 605 & 5.09 & 0.82 \\
BCS & 3.24 & 3.16 & 0.04 & 0.10 \\
Hip height, cm & 141 & 142 & 0.38 & 0.63 \\
Hip width, cm & 54.0 & 53.6 & 0.31 & 0.16 \\
Body length, cm & 165 & 165 & 0.71 & 0.91 \\
Heart girth, cm & 201 & 201 & 0.86 & 0.87 \\
Cannon bone, ${ }^{2} \mathrm{~cm}$ & 27.7 & 27.8 & 0.11 & 0.45 \\
Pelvic height, cm & 17.5 & 17.5 & 0.15 & 0.81 \\
Pelvic width, cm & 16.3 & 16.4 & 0.14 & 0.81 \\
Pelvic area, cm ${ }^{2}$ & 218 & 218 & 3.22 & 0.98 \\
Pelvic length, cm & 55.3 & 55.6 & 0.66 & 0.65 \\
ADG 170 to 410 d, kg/d & 0.85 & 0.83 & 0.03 & 0.48 \\
ADG 410 to 650 d, kg/d & 0.85 & 0.86 & 0.02 & 0.40 \\
Blood P, ${ }^{3}$ mg/dL & 8.21 & 8.26 & 0.47 & 0.93 \\
Blood P, ${ }^{4}$ mg/dL & 7.31 & 7.60 & 0.22 & 0.20 \\
\hline${ }^{1}$ NP $=$ no supplemental P, SP = supplemental P. & & & \\
${ }^{2}$ Value is indicated cannon bone circumference. & & & \\
${ }^{3}$ Measurement taken at 8 mo of age. & & & & \\
${ }^{4}$ Measurement taken at 18 mo of age. & & & &
\end{tabular}

increase in dietary P. Fradinho et al. (2006) discovered no difference in hip height, heart girth, or cannon bone circumference of foals fed diets containing 0.27 and $0.43 \% \mathrm{P}$ from weaning to $1 \mathrm{yr}$ of age.

With respect to heifer BW growth or skeletal development, our data do not support supplementation with $\mathrm{P}$ for dairy heifer diets if the endogenous dietary $\mathrm{P}$ meets the NRC (2001) requirements for growing heifers.

\section{Blood Phosphorus Concentrations}

Blood P concentrations measured on a treatment and breed balanced subset of heifers $(\mathrm{n}=122)$ at 8 and $18 \mathrm{mo}$ of age are presented in Table 2. No difference between blood $\mathrm{P}$ concentrations were detected in this study, although a slight numerical increase $(P$ $=0.20)$ was observed for heifers fed SP $(7.60 \mathrm{mg} / \mathrm{dL})$ over heifers fed NP $(7.31 \mathrm{mg} / \mathrm{dL})$. In the companion study of Esser et al. (2009), supplementing P resulted in a numerically greater bone $\mathrm{P}$ concentration $(P=$ $0.07)$. Other studies with growing ruminants, such as Hurley et al. (1982), have observed increased blood P concentrations with increased dietary $\mathrm{P}$, whereas Koch and Mahan (1985) noted an increase in bone P content with an increase in dietary $\mathrm{P}$. These studies did not, however, demonstrate any corresponding change in bone growth or body growth.

\section{Nutrient Excretion}

Least squares means for DM, N, and P contents of the experimental diets fed during the fecal collection periods, excretion, and apparent $\mathrm{N}$ and $\mathrm{P}$ retentions are presented in Table 3. The $\mathrm{N}$ concentration of feed, as a percentage of $\mathrm{DM}$, did not differ $(P=0.17)$ between dietary treatments. The similarity in $\mathrm{N}$ concentration was expected, because treatment diets were balanced to differ only in the amount of $\mathrm{P}$. The expected difference $(P<0.01)$ in dietary $\mathrm{P}$ concentrations for heifers offered NP or SP diets during the nutrient excretion collection periods was observed at 0.30 and $0.38 \% \mathrm{P}$, respectively. Because DMI of heifers offered NP and SP diets did not differ $(P=0.38)$, but dietary concentrations of $\mathrm{P}$ did differ $(P<0.01), \mathrm{P}$ intake of SP diets $(35.7 \mathrm{~g} / \mathrm{d})$ was greater $(P=0.05)$ than that of NP diets $(30.7 \mathrm{~g} / \mathrm{d})$. Logically, with similar dietary $\mathrm{N}$ concentrations and an increase in dietary $\mathrm{P}$ concentration as a consequence of supplementation, the feed N:P ratio for SP diets was less $(P<0.01)$ than that observed for NP.

The percentage of $\mathrm{N}$ in excretions, expressed as a percentage of $\mathrm{DM}$, did not differ $(P=0.65)$ with treatment, nor did the amount $(\mathrm{g} / \mathrm{d})$ of $\mathrm{N}$ excreted by heifers $(P=0.77)$. Heifers offered NP diets excreted manure with lesser $(P=0.01) \mathrm{P}$ concentrations $(0.54$ vs. $0.70 \%$ of $\mathrm{DM}$ ). Actual $\mathrm{P}$ excretions (24.2 vs. 29.2 $\mathrm{g} / \mathrm{d})$ were similarly less $(P=0.06)$ for heifers offered the NP diet. As with dietary N:P ratio, the manure $\mathrm{N}: \mathrm{P}$ ratio also differed $(P<0.01)$, with the ratio being greater for heifers offered the NP diets (5.90 vs. 4.67). The apparent retention $(\mathrm{g} / \mathrm{d})$ of $\mathrm{N}$ and $\mathrm{P}$ did not differ $(P \geq 0.88)$ with treatment, nor did the efficiency of $\mathrm{N}$ or $\mathrm{P}$ utilization $(P \geq 0.71)$.

Nutrient excretion techniques used in this study have some limitations. Pen fecal nutrient excretion data were 


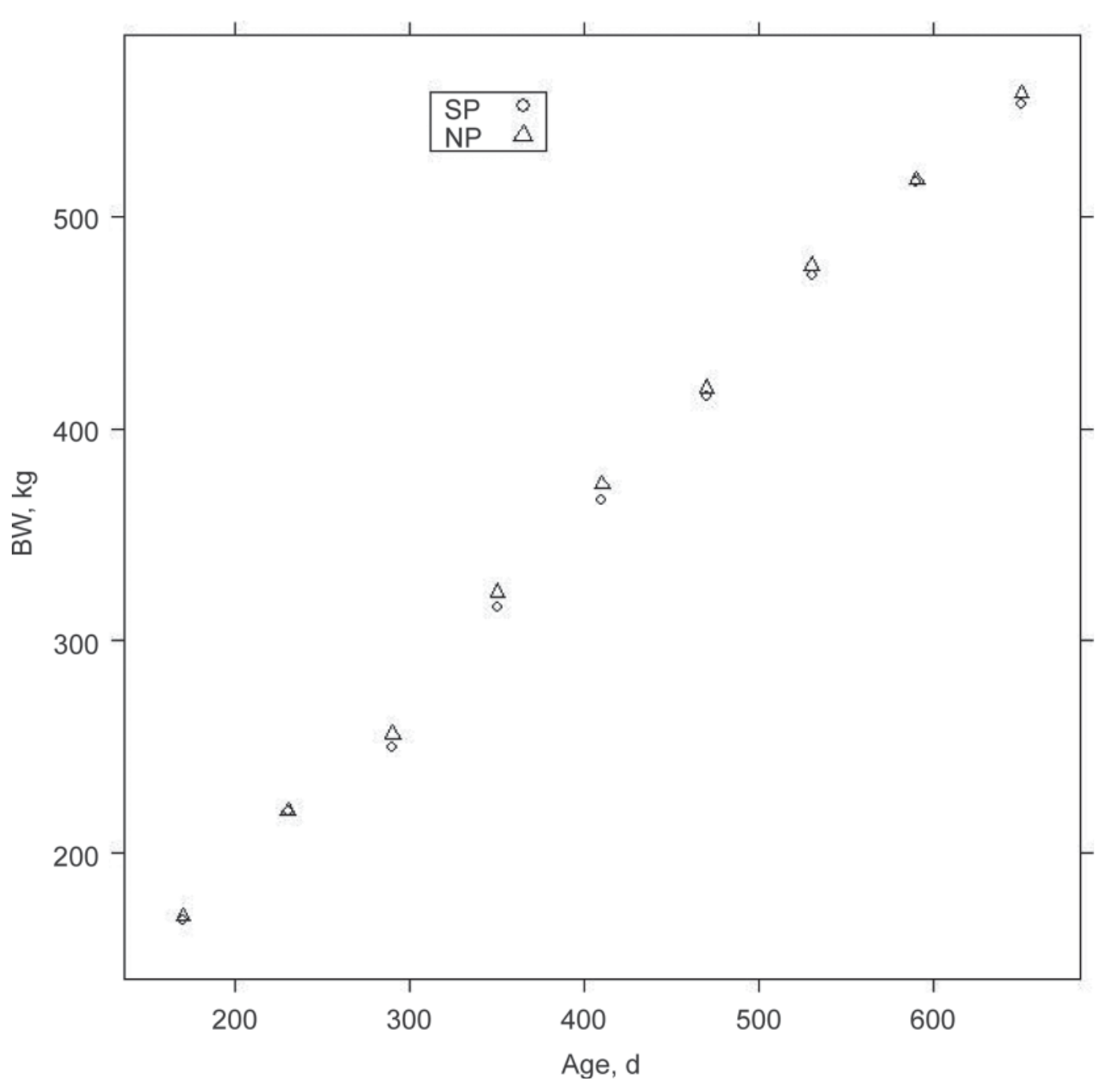

Figure 1. Body weight at 60-d intervals of heifers fed diets supplemented (SP; $0.40 \%$ of DM) or not supplemented (NP; $0.30 \%$ of DM) with $\mathrm{P}$ from 4 to 22 mo of age.

collected on a large number of heifers $(\mathrm{n}=176)$ over the duration of the growth phase of the experiment, but excretion data only represent nutrient excretions during the spot sampling periods. Despite shortcomings, the nutrient excretion data corroborate the heifer growth data. Even though heifers offered SP consumed $5.0 \mathrm{~g} / \mathrm{d}$ more $\mathrm{P}$, apparent $\mathrm{P}$ retention did not differ, and heifers offered SP also excreted $5.0 \mathrm{~g} / \mathrm{d}$ more $\mathrm{P}$ than heifers offered the NP diet. These data suggest that all of the residual $\mathrm{P}$ consumed by $\mathrm{SP}$ heifers was excreted and never utilized. In cows, Morse et al. (1992) observed a similar relationship between $\mathrm{P}$ intake and $\mathrm{P}$ excretion. Cows were offered diets with $\mathrm{P}$ concentrations of 0.30 , 0.41 , and $0.56 \%$ of dietary DM. The P excreted by cows increased linearly with the concentration of $\mathrm{P}$ in the diet, with almost the entire difference between the higher and lower concentration being excreted. Wu et al. (2000) fed diets with concentrations of $0.31,0.40$, and $0.49 \% \mathrm{P}$ to lactating dairy cows and again, cows offered greater amounts of $\mathrm{P}$ subsequently excreted greater amounts of P. Hill et al. (2007) fed dairy heifers diets varying in forage content. Dietary P concentrations were 0.30 to $0.40 \%$ of $\mathrm{DM}$, and $\mathrm{P}$ retention analysis indicated that almost no supplemental $\mathrm{P}$ was retained by these heifers, concluding that concentrations such as these constitute overfeeding $\mathrm{P}$ to heifers. As previous studies involved lactating cows (Morse et al., 1992; Wu et al., 2000) or a shorter period of the heifer-rearing process (Hill et al., 2007), the current study solidifies the evidence that overfeeding $\mathrm{P}$ in this period is unnecessary and possibly detrimental, with the added cost of supplemental $\mathrm{P}$ and increased $\mathrm{P}$ in manure.

\section{Health, Reproductive, and Production Traits}

Least squares means of heifer reproductive efficiency, dystocia, calf BW, and carryover effects on primiparous 
Table 3. Least squares means of $\mathrm{P}$ intake, excretion, and apparent retention in heifers offered diets with or without supplemental $\mathrm{P}$ during pen nutrient excretion collection periods

\begin{tabular}{|c|c|c|c|c|}
\hline \multirow[b]{2}{*}{ Item } & \multicolumn{2}{|c|}{ Treatment $^{1}$} & \multirow[b]{2}{*}{$\mathrm{SE}$} & \multirow[b]{2}{*}{$P$-value } \\
\hline & NP & $\mathrm{SP}$ & & \\
\hline \multicolumn{5}{|l|}{ Intake } \\
\hline $\mathrm{DM}, \mathrm{kg} / \mathrm{d}$ & 9.38 & 8.70 & 1.64 & 0.38 \\
\hline $\mathrm{N}, \%$ of $\mathrm{DM}$ & 2.08 & 2.21 & 0.09 & 0.17 \\
\hline $\mathrm{P}, \%$ of $\mathrm{DM}$ & 0.30 & 0.38 & 0.01 & $<0.01$ \\
\hline $\mathrm{N}, \mathrm{g} / \mathrm{d}$ & 194 & 188 & 14.6 & 0.71 \\
\hline$P, g / d$ & 30.7 & 35.7 & 2.4 & 0.05 \\
\hline Feed N:P ratio & 7.06 & 5.75 & 0.40 & $<0.01$ \\
\hline \multicolumn{5}{|l|}{ Excretion } \\
\hline $\mathrm{DM}, \mathrm{kg} / \mathrm{d}$ & 4.48 & 4.35 & 0.97 & 0.78 \\
\hline $\mathrm{N}, \%$ of $\mathrm{DM}$ & 3.15 & 3.24 & 0.21 & 0.65 \\
\hline $\mathrm{P}, \%$ of $\mathrm{DM}$ & 0.54 & 0.70 & 0.05 & 0.01 \\
\hline $\mathrm{N}, \mathrm{g} / \mathrm{d}$ & 141 & 137 & 13.5 & 0.77 \\
\hline $\mathrm{P}, \mathrm{g} / \mathrm{d}$ & 24.2 & 29.2 & 2.5 & 0.06 \\
\hline Manure N:P ratio & 5.90 & 4.67 & 0.32 & $<0.01$ \\
\hline \multicolumn{5}{|l|}{ Apparent retention } \\
\hline $\mathrm{N}, \mathrm{g} / \mathrm{d}$ & 53.9 & 52.5 & 9.0 & 0.88 \\
\hline $\mathrm{P}, \mathrm{g} / \mathrm{d}$ & 3.8 & 3.7 & 1.8 & 0.96 \\
\hline \multicolumn{5}{|l|}{ Nutrient efficiency $^{2}$} \\
\hline $\mathrm{N}$ efficiency, $\%$ & 27.4 & 27.4 & 4.8 & 0.99 \\
\hline P efficiency, \% & 13.0 & 10.9 & 5.4 & 0.71 \\
\hline
\end{tabular}

cow reproductive efficiency and health are presented in Table 4. Services per conception, age at pregnancy, and gestation length of heifers did not differ $(P \geq 0.61)$ between dietary treatments. Heifers requiring calving assistance were few $(\leq 16.0 \%)$ and percentages did not differ $(P=0.88)$ across treatments. Calves born to heifers offered NP or SP diets were of similar $(P=$ $0.22)$ BW. No differences $(P \geq 0.21)$ in first-lactation reproductive efficiency, including DIM at first breeding, services per conception, days open, and the percentage of primiparous cows pregnant by 150 and $250 \mathrm{~d}$ postpartum were observed between cows offered NP or SP diets as heifers. Cows offered SP diets as heifers had a greater $(P=0.02)$ recorded incidence of clinical mastitis $(40.5 \%)$ than cows offered the NP diet as heifers $(28.6 \%)$. No literature has been found to support the notion that differences in heifer dietary $\mathrm{P}$ lead to differences in the incidence of clinical mastitis. No differences $(P=0.47)$ were observed for the average log SCC, thereby suggesting that our differences in clinical mastitis may be random. No differences $(P \geq 0.35)$ in the incidence of hoof disease or injury were exhibited between cows offered NP or SP diets as heifers.

Previous studies have reported a similar lack of effect of increasing dietary $\mathrm{P}$ on reproductive performance. Hurley et al. (1982) noted no difference in estrous behavior in heifers fed low, medium, and high amounts of dietary P. Wu et al. (2000) concluded that increasing dietary $\mathrm{P}$ above the required amount did not affect reproductive performance in lactating dairy cows. A study of the reproductive performance in Hereford beef heifers (Call et al., 1978) also concluded that varying amounts of dietary $\mathrm{P}$ did not affect the pregnancy rate or the percentage of live calves born.

Least squares means for first-lactation milk yield, fat yield, protein yield, log SCC, MUN, and milking speed are presented in Table 5 . No differences $(P \geq 0.57)$ were observed for 305-d milk yield, 305-d mature-equivalent yield, peak milk yield, or total milk yield between cows offered NP or SP diets as heifers. Milk component traits, such as total fat yield, total protein yield, and $3.5 \%$ FCM yield also did not differ $(P \geq 0.34)$ on the basis of diet as growing heifers, nor did average log SCC, MUN, or milking speed $(P \geq 0.29)$.

Results presented in this study indicated that supplementing $\mathrm{P}$ to heifers had no effect on growth or body size at calving. Possible justification for feeding excess $\mathrm{P}$ to heifers had been to increase body size at first calving, which in turn would result in greater first-lactation milk yield. However, because no increases in body size were discovered, the results regarding lactation traits were not surprising. In addition, the nutrient excretion data indicated that no fraction of the supplemental $\mathrm{P}$ was retained by SP heifers, further suggesting that the excess $\mathrm{P}$ would not have an effect on future performance. In previous studies, Wu et al. (2000) noted no difference $(P>0.05)$ in 305-d milk yield, 3.5\% daily FCM yield, fat yield, protein yield, and SCC when P 
Table 4. Least squares means of heifer reproductive efficiency, dystocia, calf BW, and carryover effects of primiparous cow reproductive efficiency and health when offered diets with or without supplemental P from 4 to 22 mo of age

\begin{tabular}{|c|c|c|c|c|}
\hline \multirow[b]{2}{*}{ Item } & \multicolumn{2}{|c|}{ Treatment $^{1}$} & \multirow[b]{2}{*}{$\mathrm{SE}$} & \multirow[b]{2}{*}{$P$-value } \\
\hline & NP & $\mathrm{SP}$ & & \\
\hline \multicolumn{5}{|l|}{ Growth phase } \\
\hline Services per conception as heifer & 1.49 & 1.44 & 0.11 & 0.64 \\
\hline Age pregnant, d & 452 & 452 & 5.0 & 0.94 \\
\hline Gestation length, d & 275 & 275 & 0.7 & 0.61 \\
\hline \multicolumn{5}{|l|}{ Parturition } \\
\hline Dystocia index ${ }^{2}$ & 15.3 & 16.0 & 2.2 & 0.88 \\
\hline Calf BW, kg & 42.7 & 42.0 & 1.3 & 0.22 \\
\hline \multicolumn{5}{|l|}{ Lactation phase } \\
\hline DIM first breeding & 76.4 & 75.7 & 1.1 & 0.55 \\
\hline Services per conception & 1.88 & 2.00 & 0.11 & 0.21 \\
\hline Days open & 146 & 154 & 7.7 & 0.47 \\
\hline Percentage pregnant at $150 \mathrm{~d}^{3}$ & 75.2 & 71.4 & 3.9 & 0.45 \\
\hline Percentage pregnant at $250 \mathrm{~d}^{3}$ & 92.1 & 90.7 & 2.9 & 0.60 \\
\hline Clinical mastitis ${ }^{4}$ & 28.6 & 40.5 & 3.4 & 0.02 \\
\hline Hoof disease ${ }^{4}$ & 21.3 & 21.5 & 3.1 & 0.97 \\
\hline Injury $^{4}$ & 35.1 & 27.6 & 2.5 & 0.35 \\
\hline
\end{tabular}

was supplemented above NRC (2001) requirements. Furthermore, Knowlton and Herbein (2002) observed no difference in milk yield of lactating dairy cows fed luxury amounts of dietary P.

\section{CONCLUSIONS}

The results presented herein suggest that feeding the NRC (2001) requirement of $\mathrm{P}$ to heifers is sufficient for heifer frame growth, health, reproductive efficiency, and lactation yield. This study is unique, as a large number of heifers were examined and detailed measurements were made on a variety of productive and reproductive criteria. The excess $\mathrm{P}$ offered by many dairy producers to heifers is not required if endogenous $\mathrm{P}$ concentrations in the basal feeds are near NRC (2001) requirements. It is also evident from these results that excess $\mathrm{P}$ offered to heifers is not absorbed but simply excreted. Given that excess dietary P offered to heifers does not provide any growth or lactation benefits and that it is excreted by the heifer, recommendations to limit P supplementation for growing heifers can be justified. However, endogenous feed sources must contain adequate concentrations of P to meet NRC (2001) requirements.

\section{ACKNOWLEDGMENTS}

This project was supported by National Research Initiative Grant no. 2004-35205-14210 from the USDA

Table 5. Least squares means of first lactation production for primiparous cows offered diets with or without supplemental P from 4 to 22 mo of age

\begin{tabular}{lcccc}
\hline & \multicolumn{2}{c}{ Treatment $^{1}$} & & \\
\cline { 2 - 3 } Item & $\mathrm{NP}$ & $\mathrm{SP}$ & $\mathrm{SE}$ & $P$-value \\
\hline Milk 305 d, kg & 8,702 & 8,714 & 291 & 0.93 \\
Milk 305 d ME, $^{2} \mathrm{~kg}$ & 10,387 & 10,323 & 436 & 0.75 \\
Peak milk, kg & 34.7 & 34.4 & 1.3 & 0.57 \\
Total milk, kg & 8,312 & 8,417 & 535 & 0.67 \\
Total fat, kg & 330 & 328 & 20.9 & 0.85 \\
Total protein, kg & 274 & 278 & 16.6 & 0.67 \\
3.5\% FCM, kg & 31.0 & 31.5 & 1.2 & 0.34 \\
Log SCC & 2.84 & 2.73 & 0.16 & 0.47 \\
MUN, mg/dL & 14.5 & 14.5 & 0.25 & 0.95 \\
Milking speed, min/milking & 5.43 & 5.61 & 0.17 & 0.29 \\
\hline
\end{tabular}

${ }^{1} \mathrm{NP}=$ no supplemental $\mathrm{P}, \mathrm{SP}=$ supplemental $\mathrm{P}$.

${ }^{2}$ Mature equivalent. 
Cooperative State Research, Education, and Extension Service.

\section{REFERENCES}

AOAC. 1990. Official Methods of Analysis. 15th ed. Association of Official Analytical Chemists, Arlington, VA.

Call, J. W., J. E. Butcher, J. T. Blake, R. A. Smart, and J. L. Shupe. 1978. Phosphorus influence on growth and reproduction of beef cattle. J. Anim. Sci. 47:216-225.

Cole, J. B., R. C. Goodling, G. R. Wiggans, and P. M. VanRaden 2005. Genetic evaluation of calving ease for Brown Swiss and Jersey bulls from purebred and crossbred calvings. J. Dairy Sci. 88:1529-1539.

Erickson, G. E., T. J. Klopfenstein, C. T. Milton, D. Brink, M. W Orth, and K. M. Whittet. 2002. Phosphorus requirement of finishing feedlot calves. J. Anim. Sci. 80:1690-1695.

Erickson, G. E., T. J. Klopfenstein, C. T. Milton, D. Hanson, and C. Calkins. 1999. Effects of dietary phosphorus on finishing steer performance, bone status, and carcass maturity. J. Anim. Sci. $77: 2832-2836$.

Esser, N. M., P. C. Hoffman, W. K. Coblentz, M. W. Orth, and K. A. Weigel. 2009. The effect of dietary phosphorus on bone development in dairy heifers. J. Dairy Sci. 92:1741-1749.

Fradinho, M. J., G. Ferreira-Dias, L. Mateus, M. F. Santos-Silva, R. Agricola, M. Barbosa, and J. M. Abreu. 2006. The influence of mineral supplementation on skeletal formation and growth in Lusitano foals. Livest. Sci. 104:173-181.

Hill, S. R., K. F. Knowlton, R. E. James, R. E. Pearson, G. L. Bethard, and K. J. Pence. 2007. Nitrogen and Phosphorus retention and excretion in late-gestation dairy heifers. J. Dairy Sci. 90:5634-5642.

Hoffman, P. C., and D. A. Funk. 1992. Applied dynamics of dairy replacement growth and management. J. Dairy Sci. 75:2504-2516.

Hurley, W. L., L. A. Edgerton, D. Olds, and R. W. Hemken. 1982. Estrous behavior and endocrine status of dairy heifers with varied intakes of phosphorus. J. Dairy Sci. 65:1979-1986.

Knowlton, K. F., and J. H. Herbein. 2002. Phosphorus partitioning during early lactation in dairy cows fed diets varying in phosphorus content. J. Dairy Sci. 85:1227-1236.
Knowlton, K. F., J. S. Radcliffe, C. L. Novak, and D. A. Emmerson. 2004. Animal management to reduce phosphorus losses to the environment. J. Anim. Sci. 82(E. Suppl. 1):E173-E195.

Koch, M. E., and D. C. Mahan. 1985. Biological characteristics for assessing low phosphorus intake in growing swine. J. Anim. Sci. 60:699-708.

Lang, K. J., B. D. Nielson, K. L. Waite, G. M. Hill, and M. W. Orth 2001. Supplemental silicon increases plasma and milk silicon concentration in horses. J. Anim. Sci. 79:2627-2633.

Morse, D., H. H. Head, and C. J. Wilcox. 1992. Disappearance of phosphorous in phytate from concentrates in vitro from rations fed to lactating dairy cows. J. Dairy Sci. 75:1979-1986.

National Research Council. 2001. Nutrient Requirements for Dairy Cattle. 7th rev. ed. National Academy of Sciences, Washington, DC.

Noller, C. H., A. G. Castro, W. E. Wheeler, D. L. Hill, and N. J. Moeller. 1977. Effect of phosphorous supplementation on growth rate, blood minerals, and conception rate in dairy heifers. J. Dairy Sci. 60:1932-1940

Peterson, A. B., M. W. Orth, J. P. Goff, and D. K. Beede. 2005. Periparturient responses of multiparous Holstein cows fed different dietary phosphorus concentrations prepartum. J. Dairy Sci. $88: 3582-3594$

R Foundation for Statistical Computing. 2008. Version 2.72. http:// www.r-project.org/.

Schulte, E. E., J. B. Peters, and P. R. Hodgson. 1987. Wisconsin procedures for soil testing, plant analysis and feed and forage analysis. Dept. Soil Sci. Bull. No. 6. University of Wisconsin, Madison.

St-Pierre, N. R. 2007. Design and analysis of pen studies in the animal sciences. J. Dairy Sci. 90(E-Suppl.):E87-E99.

Varel, V. H., J. A. Nienaber, and H. C. Freetly. 1999. Conservation of nitrogen in cattle feedlot waste with urease inhibitors. J. Anim. Sci. $77: 1162-1168$

Wu, Z., L. D. Satter, and R. Sojo. 2000. Milk production, reproductive performance, and fecal excretion of phosphorus by dairy cows fed three amounts of phosphorus. J. Dairy Sci. 83:1028-1041.

Zygarlicke, D. L., and P. C. Hoffman. 2002. A survey of replacement heifer mineral feeding practices on Wisconsin dairy operation. J. Dairy Sci. 85(Suppl. 2):13. (Abstr.) 